JURNAL PENJAMINAN MUTU

LEMBAGA PENJAMINAN MUTU

INSTITUT HINDU DHARMA NEGERI

DENPASAR

Volume 4 Nomor 2 Agustus 2018

ISSN : 2407-912X (Cetak)

ISSN : 2548-3110 (Online)

http://ejournal.ihdn.ac.id/index.php/JPM

\title{
STRATEGI PENINGKATAN MUTU PEMBELAJARAN AGAMA HINDU DI SEKOLAH LUAR BIASA C NEGERI BANGLI
}

\author{
Oleh \\ I Made Sudana, I Ketut Sudarsana, Setyaningsih \\ Institut Hindu Dharma Negeri Denpasar \\ Sekolah Tinggi Hindu Dharma Klaten Jawa Tengah \\ iketutsudarsana@ihdn.ac.id
}

Diterima 16 Juli 2018, direvisi 31 Juli 2018, diterbitkan 31 Agustus 2018

\begin{abstract}
Selection and application of specific learning strategies to study religion. Likewise, learning with Hinduism learning strategies at Sekolah Luar Biasa C Negeri Bangli, with their disability from mental and weak dimensions or low IQ, the right strategy and in accordance with the student's background is one of the determining factors for achieving goals and the spirit of the learning process itself.

The results of the study show the following results: Strategy of learning Hinduism in Special Schools C Country Bangli is an individual learning strategy (individual learning) and exposition learning learning strategies. The stages of learning Hinduism in Sekolah Luar Biasa C Negeri Bangli are: 1) student factors, students often desire themselves and are difficult to regulate; 2) teacher factors, teachers who often have difficulty understanding students from different IQ levels of students; 3) School factors, lack of educators, facilities and planning make the teaching and learning process stunted, especially lack of learning media facilities. Efforts made in learning Hinduism in Special Schools in Bangli State $C$ are as follows: 1) attachment of special educators to Hinduism educators; 2) Provide special educatio $n$ to teaching staff such as for special education for Sekolah Luar Biasa C Negeri Bangli; 3) the teacher simplifies learning so that students have more material provided by the teacher; 4) The school strives for the appointment of classrooms, provides learning media with interesting drawings, gives more attention and prepares students from facilities in learning, and provides special learning programs for SLB C / Mentally disabled children, namely self-development and self-development.
\end{abstract}

Keywords: Quality Improvement, Hinduism Learning 


\section{PENDAHULUAN}

Pendidikan merupakan upaya menciptakan kondisi yang kondusif bagi perkembangan peserta didik, dimana pendidikan diharapkan menciptakan kondisi yang memberi kemudahan untuk mengembangkan diri peserta didik dan guru aktif membantu menciptakan kemudahan untuk perkembangan yang optimal. Apalagi di Indonesia setelah diberlakukannya otonomi daerah dibidang pendidikan akan mendorong meningkatnya partisipasi masyarakat dalam pengelolaan pendidikan serta meningkatnya pemerataan memperoleh kesempatan pendidikan. Peranpemerintah dalam penyelenggaraan pendidikan hanya mencakup dua aspek, yaitu mutu dan pemerataan. Pemerintah menetapkan standar mutu pendidikan, dengan keragaman prestasi antar sekolah di wilayah Indonesia.Pemerintah juga memberi kesempatan bagi seluruh siswa dari semua lapisan masyarakat untuk mendapatkan pendidikan.Peran ini dilakukan melalui perumusan kebijakan umum, pelayanan teknis dan monitoring program secara regular, tanpa diskriminasi terhadap siswa perempuan, siswa normal, anak berkelainan dan sekolah swasta sehingga semua warga negara berhak mendapatkan pendidikan dan pengajaran.

Pengembangan potensi diri dalam suatu proses pendidikan yang sesuai dengan tujuan pendidikan di Indonesia diselenggarakan melalui pendidikan pada jalur formal, nonformal dan informal (UU No. 20 Tahun 2013 Pasal 13 ayat 1). Khusus pada pendidikan jalur formal terdiri atas pendidikan dasar, pendidikan menengah dan pendidikan tinggi. Pendidikan formal merupakan jalur pendidikan yang terstruktur dan berjenjang. Dimana pendidikan melalui jalur formal diharapkan memberikan bekal bagi semua peserta didik mulai dari tingkatan yang paling dasar sampai pada tingkatan yang paling tinggi. Diharapkan dengan tesentuhnya pendidikan formal pada semua anak Indonesia pencapaian tujuan pendidikan yang telah dicanangkan bisa dicapai secara maksimal.
Pencapaian tujuan pendidikan, pendidik dan peserta didik tidak terlepas dari faktor-faktor penunjang seperti sarana dan prasarana pendidikan atau media pendidikan dalam proses pembelajaran. Pembelajaran pada dasarnya merupakan sebuah kegiatan yang wajib dilakukan kepada anak-anak sebagai kunci sukses untuk menggapai masa depan yang akan berguna bagi bangsa dan negara. Pembelajaran adalah proses perubahan yang relatif tetap dalam prilaku individu sebagai hasil dari pengalaman, dalam artian terjadinya suatu perubahan prilaku individu dan buah dari belajar atau pengalaman (Widiastawa, 2005: 18).

Terkait dengan uraian tersebut untuk mencapai hasil belajar dan pengalaman dalam proses pembelajaran, maka strategi pembelajaran yang efektif dan efesien adalah sebuah keharusan dalam suatu pembelajaran tersebut. Strategi pembelajaran adalah suatu pendayagunaan secara tepat dan optimal dari semua komponen yang terlibat dalam proses pembelajaran yang didalamnya meliputi tujuan, materi pelajaran, media, metode, siswa, guru, lingkungan belajar dan evaluasi. Semua komponen strategi pembelajaran tersebut tidak terlepas dari pendidikan yang diberikan kepada anak didik bersangkutan.

Kewajiban dalam memberikan strategi pembelajaran yang tepat dan efesien pada peserta didik tidak memandang dari status sosial, jenis kelamin, keadaan jasmani maupun rohani. Hal tersebut semata-mata untuk mewujudkan persamaan hak asasi manusia. Kenyataannya tidak semua anak di lahirkan dengan kondisi yang normal baik dari segi fisik maupun segi mental. Seperti itu biasanya di sebut dengan anak yang berkebutuhan khusus atau anak luar biasa salah satunya yakni SLB C.

Anak tunagrahita memiliki keterbatasan pada fisik dan mentalnya. Keterbatasan itulah yang menjadi penghambat tumbuh kembang dalam bidang pengetahuannya. Dari hal tersebut jika di kaitkan dengan strategi pembelajaran, tentunya haruslah dibedakan antara penanganan dengan strategi pembelajaran untuk anak normal pada umumnya dengan 
strategi pembelajaran bagi anak berkebutuhan khusus hal ini anak tunagrahita.

Adapun karakteristik umum tunagrahita itu adalah: 1). Keterbatasan inteligensi, dimana kapasitas belajar terbatas untuk hal abstrak. 2). Keterbatasan sosial, dimana anak tunagrahita tidak dapat mengurus diri sendiri dan cendrung meniru tanpa tau akibatnya. 3). Keterbatasan fungsi mental, dimana anak tunagrahita sukar memusatkan perhatian. 4). Jarang menghayati perasaan bangga, tanggung jawab dan hak sosial. 5). Mengalami keterlambatan dalam perkembangan sikap.

Dilihat secara rinci, kecerdasan berfikir anak tunagrahita ringan paling tinggi sama dengan kecerdasan anak normal usia 12 tahun. Mereka memiliki tingkat kecerdasan paling tinggi diantara kelompok tunagrahita yang lain, dengan IQ berkisar 50-70. Meskipun kecerdasan dan adaptasi sosialnya terhambat, namun mereka mempunyai kemampuan untuk berkembang di bidang pelajaran akademik, penyesuaian sosial, dan kemampuan bekerja (Amin, 1995:37).

Sebaliknya, anak tunagrahita sedang tidak bisa mempelajari pelajaran akademik. Mereka umumnya belajar secara membeo, perkembangan bahasanya sangat terbatas, hampir selalu bergantung pada orang lain, dapat membedakan bahaya dan bukan bahaya, masih mempunyai potensi untuk belajar memelihara dan menyesuaikan diri terhadap lingkungan, dan dapat mengerjakan pekerjaan yang mempunyai nilai ekonomi. Pada usia dewasa, baru mencapai usia yang sama dengan anak normal umur 7-8 tahun. (Amin, 1990)

Anak dengan tunagrahita berat tidak dapat membedakan bahaya, selalu tergantung pada pertolongan orang lain, kata-kata yang sangat sederhana, dan kecerdasannya hanya dapat berkembang paling tinggi sama dengan anak usia 3-4 tahun.

Ketunagrahitaan seorang anak dapat diketahui dengan melakukan observasi. Observasi dilakukkan dengan cara membandingkan anak dengan anak seusianya. Data hasil observasi dan tes spikologi dikumpulkan dan dibandingkan dengan usia anak sebenarnya. Adapun dalam tes Binet -
Simon, anak yang tergolong tungrahita atau anak dengan gangguan intelektual yaitu: 1). Debil (IQ 50-70), 2). Imbesil (IQ 30-50), 3). Idiot (IQ < 30). Angka tersebut di peroleh dari tes, dimana IQ = MA/CA X 100. Dengan CA merupakan umur anak dan MA merupakan haril tes inteligensi.

Berdasarkan hal tersebut di atas, walaupun memiliki keterbatasan seseorang yang tergolong tunagrahita sesuai dengan ketentuan undang-undang maka berhak mendapatkan pendidikan yang layak. Dengan keterbatasan yang dimiliki diperlukan treatment khusus di dalam memberikan pengajaran kepada mereka melalui strategistrategi khusus yang sesuai dengan karakteristik mereka. Strategi pembelajaran tidak hanya diberikan kepada siswa yang normal, tetapi juga kepada siswa-siswa yang mengalami gangguan intelektual yang dikenal dengan anak tunagrahita juga sudah sepantasnya. Anak tunagrahita secara nyata mengalami hambatan dan keterbelakangan perkembangan mental intelektual jauh dibawah rata-rata sehingga mengalami kesulitan dalam tugas-tugas akademik, komunikasi maupun sosial, sehingga memerlukan layanan pendidikan kebutuhan khusus.

Selain itu, adanya gagasan EFA (Education For All) yang muncul pada tahun 1990 pada Konferensi Dunia tentang pendidikan untuk semua. EFA adalah sebuah inisiatif internasional yang diluncurkan di Jomtien, Thailand, pada tahun 1990 untuk membawa manfaat dari pendidikan kepada setiap warga di setiap Negara tanpa melihat bentuk fisik. Salah satu bunyi deklarasi EFA adalah menghilangkan kekakuan, memberikan pedoman tentang sistem pendidikan dan memberikan pendidikan secara fleksibel.

Keterbatasan kecerdasan yang di miliki anak tunagrahuta menjadi kendala utama dalam belajar. Anak tunagrahita tidak mampu berkompetisi dalam belajar dengan temannya yang normal sehingga mereka seringkali menjadi bahan olok-olok sebagai anak yang bodoh di kelas.

Materi pembelajaran bagi anak tunagrahita harus di rinci dan sedapat 
mungkin di mulai dari hal-hal konkrit, mengingat mereka mengalami keterbatasan dalam berfikir abstrak. Walaupun demikian materi yang bersifat akademik tetap di berikan sampai mereka memperlihatkan ketidak mampuannya. Sebaliknya materi pelajaran keterampilan memiliki bobot yang tinggi karena melalui materi ini di harapkan mereka dapat memiliki suatu keterampilan sebagai bekal hidupnya.

Dan materi pembelajaran khususnya mata pelajaran Agama bagi anak tunagrahita harus diprogamkan secara rinci dan mendapat bobot yang tinggi pula karena tidak dapat mempelajari hal itu hanya melalui pengamatan seperti yang di lakukan anak normal.

Dalam pemberian layanan pendidikan tersebut, diperlukan strategi pembelajaran yang sesuai dengan kebutuhan anak yang mengalami keterbelakangan mental tesebut. Karena perlu diketahui dalam proses pembelajaran dibutuhkan strategi untuk memperoleh kesuksesan atau keberhasilan dalam mencapai tujuan. Dalam dunia pendidikan, pembelajaran dapat diartikan sebagai perencanaan yang berisi rangkaian kegiatan yang di desain untuk mencapai tujuan pendidikan seperti yang diharapkan. Inilah yang dikatakan sebagai strategi pembelajaran.

Menurut Uno (2008: 3), Strategi pembelajaran adalah cara-cara yang akan digunakan oleh pengajar untuk memilih kegiatan belajar yang akan digunakan selama proses pembelajaran. Pemilihan tersebut dilakukan dengan mempertimbangkan situasi dan kondisi, sumber belajar, kebutuhan dan karakteristik peserta didik yang dihadapi dalam rangka mencapai tujuan pembelajaran tertentu. Strategi pembelajaran yang dapat digunakan pada pembelajaran anak tunagrahita adalah strategi pembelajaran yang diindividualisasikan dimana mereka belajar bersama-sama dalam satu kelas tetapi kedalaman dan keluasan materi, pendekatan/metode maupun teknik berbedabeda di sesuaikan dengan kemampuan dan kebutuhan setiap peserta didik.

$$
\text { Strategi pembelajaran dalam }
$$

pengembangan mentalnya jika dikaitkan dengan ajaran agama khususnya agama Hindu juga sangat membantu anak tesebut. Dimana strategi pembelajaran agama Hindu memiliki tujuan untuk membentuk manusia atau peserta didik tersebut menjadi manusia Pancasila yang astiti bhakti kepada Sang Hyang Widhi Wasa dan membentuk moral, etika dan spiritual anak didik sesuai dengan ajaran agama Hindu (Pemda Bali,2000:2324). Salah satu sekolah yang memfasilitasi peserta didik yang tergolong tunagrahita untuk tetap dapat mengenyam bangku pendidikan adalah Sekolah Luar Biasa C Negeri Bangli. SLB C Negeri Bangli merupakan sekolah yang menaungi siswa yang bekebutuhan khusus yang mengalami hambatan dalam penglihatan (tunanetra), hambatan dalam pendengaran (tuna rungu), individu yang memiliki intelegasi yang signifikan di bawah rata-rata atau yang sering di kenal dengan keterbelakangan mental (tunagrahita), individu yang memiliki gangguan gerak (tunadaksa).

\section{METODE}

Jenis penelitian yang digunakan adalah penelitian deskriptif dengan jenis data yakni data kualitatif disajikan kedalam bentukbentuk kata yang didalamnya mengandung makna. Data merupakan fakta empiris yang dikumpulkan oleh peneliti untuk kepentingan memecahkan masalah atau menjawab pertanyaan penelitian. Peneliti dalam penelitian ini memilih metode purposive sampling, karena untuk mengumpulkan data yang dibutuhkan, sangat diperlukan informasi dari para informan. Informan yang dimaksudkan adalah orang-orang yang mengetahui dan mampu memberikan informasi yang seluas-luasnya tentang penerapan model pembelajaran pendidikan agama Hindu.Ada pula para informan yang dapat dijadikan sumber informasi, diantaranya adalah kepala sekolah, guru-guru, tenaga kependidikan dan siswa diSekolah Luar Biasa C Negeri Bangli. Metode pengumpulan data yang digunakan dalam penelitian kualitatif adalah metode seperti : (1) Observasi, (2) Wawancara (interview), (3) Dokumentasi. 
III. HASIL DAN PEMBAHASAN

1. Strategi Pembelajaran Agama Hindu di Sekolah Luar Biasa C Negeri

Bangli

Strategi pembelajaran pada dasarnya adalah suatu perangkat materi dan prosedur pembelajaran yang digunakan secara bersama-sama untuk menimbulkan hasil belajar yang efektif dan efisien pada peserta didik atau siswa (Rusman, 2011:123). Kegiatan strategi pembelajaran tersusun secara sistematis dalam mengkomunikasikan materi pembelajaran kepada peserta didik. Pemilihan dan penerapan strategi yang tepat dalam suatu proses pembelajaran akan membantu guru untuk mencapai tujuan pembelajaran yang diinginkan.

Menurut Sanjaya

(2008:124)

mengertikan strategi pembelajaran merupakan rencana tindakan termasuk penggunaan metode dan pemanfaatan berbagai sumber daya/kekuatan dalam pembelajaran untuk mencapai tujuan pendidikan tertentu. Oleh karena itu, sebelum menentukan strategi, perlu merumuskan tujuan yang jelas dan dapat di ukur keberhasilannya. Strategi pembelajaran pada dasarnya masih bersifat konseptual tentang keputusan-keputusan yang akan diambil dalam suatu pelaksanaan pembelajaran untuk mencapai tujuan yang telah ditetapkan atau penyusunansuatu strategi baru sampai pada proses penyusunan rencana kerja belum sampai pada tindakan.

Penerapan strategi pembelajaran untuk anak-anak normal pada umumnya berbeda dengan anak-anak yang berkebutuhan khusus atau memiliki ketunaan, salah satunya anak SLB C. Anak SLB C adalah anak yang memiliki intelegensi yang signifikan berada di bawah rata-rata dan disertai dengan ketidakmampuan dalam adaptasi prilaku yang muncul dalam masa perkembangan, mereka juga tidak dapat mencapai kemandirian yang sesuai dengan ukuran (standar) kemandirian dan tanggung jawab sosial, hal tersebut sama seperti anak-anak Sekolah Luar Biasa C Negeri Bangli.

Penerapan strategi pembelajaran di Sekolah Luar Biasa C Negeri Bangli disesuaikan dengan tujuan dan sasaran dari materi pelajaran yang ingin dicapai, yakni dengan menggunakan Kurikulum Tingkat Satuan Pendidikan (KTSP) yang merupakan penyempurnaan dari kurikulum 2004 yaitu Kurikulum Berbasis Kopetensi (KBK). Kurikulum Tingkat Satuan Pendidikan membantu peserta didik berkembang dalam kopetensi pengetahuan (kognitif), nilai-nilai (afektif) dan keterampilan (psikomotor) yang digunakan dalam berbagai bidang kehidupan. Penerapan Kurikulum Tingkat Satuan Pendidikan dalam sistem pendidikan Indonesia tidak sekedar pergantian kurikulum, tetapi menyangkut perubahan fundamental dalam sistem pendidikan. Penerapan Kurikulum Tingkat Satuan Pendidikan menuntut perubahan paradigma dalam pembelajaran dan persekolahan, karena dalam penerapanya tidak hanya menyebabkan perubahan konsep, metode, dan strategi guru dalam mengajar, tetapi juga menyangkut pola pikir, filosifi, komitmen guru, sekolah, dan stakeholder pendidikan (Kunandar, 2007:112-113).

Kaitannya dengan pembelajaran agama Hindu, Kurikulum Tingkat Satuan Pendidikan yang digunakan di Sekolah Luar Biasa C Negeri Bangli yaitu menggunakan Kurikulum Tingkat Satuan Pendidikan berbasis Tematik. Menurut Widiantari (wawancara, 17 juni 2016) selaku guru kelas di Sekolah Luar Biasa C Negeri Bangli menyatakan bahwa, "Kurikulum Tingkat Satuan Pendidikan (KTSP) berbasis Tematik di berlakukan pada tahun 2011/2012, dengan indikator yang disesuaikan dengan kemampuan dari peserta didik secara individual". Pembelajaran agama Hindu yang diajarkan di Sekolah Luar Biasa C Negeri Bangli bertujuan untuk membantu menumbuh kembangkan dan meningkatkan sradha dan bhakti melalui pemberian, pemupukkan, penghayatan dan pengamalan ajaran agama khususnya agama Hindu. Menurut Sukarsa (wawancara, 19 juni 2016) selaku guru pendidikan agama Hindu menyatakan bahwa, Pemberian pembelajaran agama Hindu dititik beratkan pada praktek (keterampilan) $60 \%$ dan $40 \%$ pemberian materi, sehingga diharapkan dari sanalah dapat membentuk 
keyakinan serta pengalamannya dalam beragama dimasyarakat, seperti mampu melakukan puja Tri Sandya di pagi hari, persembahyangan dalam kegiatan keagamaan, saling menghormati dan memiliki kasih sayang sesama teman sejawat.

Kegiatan pembelajaran agama Hindu di Sekolah Luar Biasa C Negeri Bangli menurut Agung (wawancara, 19 juni 2016) selaku guru pendidikan agama Hindu menyatakan bahwa, "ruang lingkup materi agama Hindu yang diajarkan di Sekolah Luar Biasa C Negeri Bangli meliputi: kemahakuasaan Tuhan, memahami Sad Ripu, Sapta Timira, Yadnya, $W e d a$, orang suci, hari suci, kepemimpinan, Bhuana Agung dan Bhuana Alit, Dharma Gita dan sejarah agama Hindu".

Dalam penerapannya pembelajaran agama Hindu tentunya memerlukan strategi pembelajaran yang tepat sesuai dengan keadaan peserta didik yang melihat dari ketunaan yang dimiliki dari segi mental dan IQ yang rendah, tentunya hal tersebut juga merupakan salah satu faktor penentu tercapainya tujuan dan keberhasilan dari proses pembelajaran. Menurut Swarni (wawancara, 17 juni 2016) selaku guru kelas khusus anak SLB C Negeri Bangli menyatakan bahwa, "penerapan strategi pembelajaran khususnya pembelajaran agama Hindu disesuaikan dengan kemampuan dan daya tangkap siswa dengan menggunakan strategi pembelajaran individual (individual learning), dimana guru yang mengikuti keinginan siswa, bukan siswa yang mengikuti keinginan guru".

Menurut Sudjana (2009:116) strategi individual learning merupakan suatu upaya untuk memberikan kesempatan kepada siswa agar dapat belajar sesuai dengan kebutuhan, kemampuan, kecepatan dan saranya sendiri. Strategi individual learning adalah kegiatan pembelajaran yang menitikberatkan bantuan dan bimbingan belajar kepada masing-masing individual. Strategi individual learning tidaklah berarti bahwa pengajaran harus berdasarkan atas jalannya satu orang guru dengan satu orang murid akan tetapi pembelajaran yang berjalan secara bersama dan guru harus memberikan pelayanan yang berbeda setiap anak sesuai dengan perbedaanperbedaan individual siswa. Dengan demikian strategi individual learning merupakan usaha melengkapi kondisi belajar yang optimum bagi setiap individual. Pada strategi individual learning ini siswa dapat belajar secara mandiri, tanpa adanya beban pada saat proses pembelajaran.

Strategi individual learning menurut Sanjaya (2008:128), memiliki kelebihan dan kelemahan yaitu:

a. Kelebihan menggunakan strategi ini adalah terbangunnya rasa percaya diri siswa, siswa menjadi mandiri dalam melaksanakan pembelajaran, siswa tidak memiliki ketergantungan kepada orang lain. Peserta didik dapat menyesuaikan diri dengan kemampuan rata-rata kelas. Pengembangan kemampuan tiap individu secara optimal, tiap individu memiliki paket belajar sendiri-sendiri, yang sesuai dengan tujuan belajarnya secara individual juga. Posisi peserta didik dalam pengajaran bersifat sentral, keleluasaan belajar berdasarkan kemampuan sendiri, dan ada kebebasan menggunakan waktu belajar.

b. Kelemahan strategi pembelajaran ini, diantaranya jika siswa menemukan kendala dalam pembelajaran, minat dan perhatian siswa justru dikhawatirkan berkurang karena kurangnya komunikasi belajar antar siswa, sementara enggan bertanya kepada guru, tidak membiasakan siswa bekerjasama dalam sebuah team.

Hal senada ditambahkan oleh Agung 18 juni 2016, gurupendidikan agama Hindu bahwa, jangka waktu penerapan strategi pembelajaran individual dalam agama Hindu tidak bisa dilaksanakan hanya dengan satu kali tatap muka, akan tetapi dapat mencapai pertemuan hingga beberapa kali. Apabila pada saat pertemuan siswa sudah dapat memahami materi yang diberikan, maka untuk selanjutnya sudah bisa diganti dengan tema yang lainnya. 
Strategi pembelajaran khususnya pembelajaran agama Hindu di Sekolah Luar Biasa C Negeri Bangli tentunya tidak hanya cukup dengan menggunakan satu strategi saja, akan tetapi strategi lainnya mungkin saja bisa di terapkan. Menurut Agung (wawancara, 19 juni 2016) menyatakan bahwa, "strategi pembelajaran agama Hindu juga menggunakan strategi pembelajaran exposition learning yakni dengan menerapkan metode ceramah dan metode direct introduction". Strategi exposition learning adalah suatu pembelajaran dimana seorang guru langsung memberikan materi pembelajaran pada peserta didik di kelas. Bahan pembelajaran dalam strategi ini disajikan kepada peserta didik dalam bentuk jadi dan peserta didik dituntut untuk menguasai bahan tersebut. Dengan demikian dalam strategi exposition guru hanya berfungsi sebagai penyampai informasi. Menurut Martinis (2012:65) metode ceramah merupakan metode yang disajikan secara lisan atau penjelasan langsung kepada peserta didik. Dalam metode ini peserta didik bersifat pasif menerima penjelasan guru.

Kelebihan dan kelemahan strategi ini menurut Rowntree (dalam Sanjaya, 2008:128), sebagai berikut:

1. Kelebihan strategi ini yaitu, dalam penerapannya guru dapat mengontrol urutan dan keleluasaan materi pembelajaran, serta mengukur sejauh mana peserta didik menguasai bahan pembelajaran yang di sampaikan.

2. Kelemahan strategi ini yaitu, dalam penerapannya tidak dapat melayani perbedaan kemampuan individu peserta didik, baik dari segi pengetahuan, bakat serta gaya belajar yang mereka miliki. Selain itu, keberhasilan strategi ini sangat tergantung kepada apa yang dimiliki oleh guru, seperti persiapan, semangat, rasa sabar, kemampuan bertutur kata serta memotivasi peserta didik dalam kegiatan pembelajaran.

Sedangkan metode direct introduction menurut Wantah (2007:11) merupakan metode pengajaran yang menggunakan pendekatan tahap demi tahap yang terstruktur dengan cermat, dalam memberikan instruksi atau perintah. Menurut Sukarsa (wawancara, 21 juni 2016) selaku guru pendidikan agama Hindu menyatakan bahwa,

penerapan strategi pembelajaran exposition learning dilakukan dengan cara memadukan metode ceramah dan metode direct introduction, dimana guru merancang pelajaran secara cermat, dan memberikan kepada peserta didik dengan cara melakukan umpan balik seperti guru menjelaskan materi pembelajaran didepan kelas kepada siswa dengan mengerahkan daya upaya ekspresi dan mimik wajah, gerak bibir, serta penggunaan media (gambar hewan, tumbuhan, dan lingkungan hidup) dan peserta didik menjawab materi pembelajaran yang guru berikan. Hal tersebut untuk dapat menarik minat siswa dalam mendengarkan materi yang disampaikan guru, serta mengoreksi dan memberikan kesempatan melatih keterampilan peserta didik tersebut sehingga nantinya dapat memberikan kesempatan pengalaman pembelajaran yang positif dan meningkatkan kepercayaan diri dan motivasi belajar anak SLB C untuk berprestasi.

Berdasarkan hasil wawancara dari beberapa informan diatas, maka dapat disimpulkan bahwa strategi pembelajaran yang diterapkan dalam pembelajaran agama Hindu adalah strategi pembelajaran individual (individual learning) dan strategi pembelajaran exposition learning. Kedua strategi tersebut sangat baik dan cocok diterapkan dalam pembelajaran agama Hindu di Sekolah Luar Biasa C Negeri Bangli, walaupun tak jarang terdapat beberapa kendala didalam penerapan strategi tersebut.

\section{Kendala-kendala dalam Pembelajaran Agama Hindu di Sekolah Luar Biasa C Negeri Bangli}

Keberhasilan dalam pelaksanaan suatu pembelajaran merupakan suatu pencapaian di dalam kegiatan pembelajaran itu sendiri. Keberhasilan tersebut menuntut guru untuk berusaha sekuat tenaga dan pikiran dalam 
mempersiapkan program pengajarannya dengan baik dan sistematis. Namun kenyataanya, masih banyak keberhasilan tidak bertahan lama, hal tersebut dikarenakan adanya beberapa kendala serta faktor yang ditemui dalam proses penerapannya.

Kendala juga dapat terjadi karena adanya kesenjangan antara tujuan yang diinginkan dengan kenyataan yang ada. Menurut Agung (wawancara, 21 juni 2016) selaku guru pendidikan agama Hindu menyatakan bahwa, "kendala dalam pelaksanaan strategi pembelajaran agama Hindu di Sekolah Luar Biasa C Negeri Bangli di pengaruhi oleh beberapa faktor yakni dari siswa, guru, dan sekolah".

\section{a. Faktor Siswa}

Siswa merupakan salah satu komponen yang memiliki peranan terpenting di dalam pelaksanaan kegiatan pembelajaran. Dalam proses pembelajaran siswa dikatakan sebagai organisme yang unik yang berkembang sesuai dengan tahap perkembangannya. Perkembangan pada siswa adalah perkembangan seluruh aspek kepribadiaannya, akan tetapi perkembangan masing-masing siswa pada setiap aspek tidak selalu sama. Proses pembelajaran dapat dipengaruhi oleh faktor perkembangan siswa yang tidak sama tersebut.

Menurut Suparno (2001:45) faktor kesulitan belajar dalam diri siswa terdiri dari beberapa faktor, diantaranya:

1) Kelemahan secara fisik, kelemahan ini biasanya terjadi Karena ada kelainan pada pusat susunan saraf, cacat, panca indra (mata, telinga, alat bicara, dan sebagainya) yang tidak berkembang dengan baik, ketidak seimbangan perkembangan yang kurang sempurna serta penyakit menahun yang dapat mengahambat usaha-usaha belajar secara optimal.

2) Kelemahan-kelemahan secara mental (baik kelemahan yang dibawa sejak lahir maupun tidak) yang sukar diatasi oleh indvidu bersangkutan dan juga oleh pendidikan.

3) Kelemahan-kelemahan emosional yakni adanya rasa tidak nyaman, penyesuaian yang kurang, rasa bosan dan bahkan sampai dengan rasa takut berlebihan.

4) Kelemahan yang disebabkan oleh kebiasaan dan sikap-sikap yang salah, seperti: malas belajar, kurang percaya diri, sering bolos dan menghindari tanggung jawab.

5) Tidak memiliki keterampilanketerampilan dan pengetahuan dasar yang diperlukan, seperti: membaca, berhitung, dan memiliki cara belajar yang salah.

Kendala-kendala tersebut juga dirasakan oleh anak di Sekolah Luar Biasa C Bangli. Menurut Agung (wawancara, 21 Juni 2016) selaku guru pendidikan agama Hindu menyatakan bahwa,

kendala dari siswa SLB C yakni kebanyakan siswa SLB C cenderung mengikuti keinginannya sendiri, selalu ingin untuk diperhatikan, dan susah untuk diatur. Dengan kondisi fisik serta psikologi IQ yang berbeda dengan anak normal lainnya, ank SLB $\mathrm{C}$ cenderung, memiliki watak keras, tidak mau tahu cepat bosan, sibuk dengan dunianya sendiri tanpa memperdulikan lingkungan sekitarnya, tak jarang juga membuat kebanyakan peserta didik tidak lancar dalam membaca dan menulis, bahkan untuk memegang alat tulis pun peserta didik belum mampu melakukannya mereka sering kali dibantu dengan bantuan orang tua.

Senada dengan hal tersebut, menurut Sukarsa (wawancara, 22 Juni 2016) menambahkan bahwa, "dengan kondisi fisik serta intelegensi IQ siswa SLB C yang rendah menyebabkan dalam penerapan pemebelajaran agama Hindu memerlukan jangka waktu yang tidak hanya satu kali pertemuan akan tetapi beberapa kali”.

Ada beberapa sifat khusus yang dimiliki oleh siswa SLB C diantaranya, tingkat intelegensinya sangat rendah, tidak dapat mengadakan generalisasi, mereka tidak dapat menggunakan pengalamannya, mereka tidak dapat menyesuaikan diri dengan situasi baru, mereka tidak mempunyai inisiatif tertentu, lebih cepat emosional, mereka 
mudah mendapat sugesti, tapi tidak dapat meramalkan hasilnya lebih dahulu dan mereka tidak mempunyai kecakapan untuk mengkritik. Insting yang timbul hanya sebentar, mudah hilang dengan demikian mereka selalu diawasi baik dari guru maupun orang tua mereka ( Soemantri 2006:32-33).

\section{b. Faktor Guru}

Proses pembelajaran di dalam pendidikan tidak terlepas dari komponen pendidik atau guru. Dalam pelaksanaan pembelajaran agama Hindu selain terdapat faktor siswa, faktor guru atau tenaga pendidik juga menjadi salah satu kendala. Pendidik pada dasarnya adalah orang dewasa yang bertanggung jawab untuk memberikan bimbingan secara sadar terhadap perkembangan, kepribadian dan kemampuan anak didik baik jasmani maupun rohani. Seorang pendidik dalam pembelajaran harus memiliki kemampuan guna mencapai apa yang dicita-citakan dalam melaksanakan pendidikan. Menurut Sudarma (wawancara, 22 Juni 2016) selaku Kepala Sekolah di Sekolah Luar Biasa C Bangli menyatakan bahwa, " kendala guru yakni dari penyampaian materi dan media yang digunakan dalam memberikan materi pembelajaran, guru dituntut harus membawa media-media pembelajaran yang berbedabeda serta menarik untuk memotivasi peserta didik agar tertarik untuk belajar, seperti media gambar (hewan, lingkungan hidup, dan tumbuhan)". Hal senada ditambahkan oleh Widyantari 22 Juni 2016 bahwa,

bagi guru mempersiapkan mediamedia yang berbeda-beda setiap pertemuan dan menarik disarankan sebagai kendala, dimana guru harus terus berinovasi dalam memberikan media-media yang berbeda kepada peserta didik, serta media yang dibuat oleh guru secara manual juga tak jarang membuat media tersebut menjadi cepat rusak. Apalagi ketika guru lupa membawa media dalam pembelajarannya, maka membuat proses pembelajaran menjadi terhambat dan membuat siswa menjadi cepat bosan dan menjadikan siswa akan lebih mementingkan aktivtasnya masing-masing.

Sehingga dapat dikatakan bahwa kendala dari guru tersebut, lebih banyak dilihat dari segi kesiapan guru dalam mempersiapkan pembelajarannya, serta dari kemampuan guru dalam menguasai kondisi dari masing-masing peserta didik yang memiliki intelegensi IQ yang berbeda-beda. Guru juga harus memiliki kesadaran extra, serta rasa kasih sayang dalam mendidik anak SLB C yang sangat berbeda dari anak normal pada umumnya, sebab dengan kondisi peserta didik tersebut membuat peserta didik susah untuk diajak berdiskusi.

\section{c. Faktor Sekolah}

Sekolah merupakan wadah dimana siswa itu menerima proses pembelajaran, namun tak jarang kendala belajar yang mereka alami datang dari tempat mereka menerima pendidikan. Di Sekolah Luar Biasa C Negeri Bangli menurut Agung (wawancara 17 Juni 2016) selaku guru kelas menyatakan bahwa, "kendala yang dihadapi sekolah terlihat dari tenaga pendidik, sarana, dan prasarana sekolah yang kurang memadai". Hal senada ditambahkan oleh Sukarsa 17 Juni 2016 bahwa, "sarana dan prasaran di Sekolah Luar Biasa C Negeri Bangli masih kurang, hal ini terlihat pada kurangnya ruang kelas, manajemen sekolah yang kurang baik, serta fasilitasnya bagi para siswa".

Dari segi sarana pendidikan juga kekurangan sehingga membuat tenaga pendidik terkadang kewalahan dalam menghadapi anak SLB C Negeri Bangli yang terlalu hiperaktif. Menurut Widiantari (wawancara, 21 Juni 2016) menyatakan bahwa, "kendala dari sekolah lainnya yakni tenaga kerja pendidik agama Hindu yang masih kurang, serta lulusan pendidik yang tidak sesuai dengan pendidikan kekhususnya untuk mengajar anak yang memiliki ketunaan".

Berdasarkan hasil wawancara dari beberapa informan diatas, dapat disimpulkan bahwa kendala-kendala dalam pembelajaran agama Hindu di Sekolah Luar Biasa C Negeri Bangli yakni: 1) faktor siswa, siswa sering mengikuti keinginan sendiri dan susah untuk 
diatur, 2) faktor guru, guru sering sulit dalam memahami keinginan siswa akibat dari kondisi psikologis peserta didik yang berbeda-beda; 3) faktor sekolah, kekurangan tenaga pendidik, sarana dan prasarana membuat terkadang proses belajar mengajar menjadi terhambat, terutama sarana media pembelajaran dan ruang kelas yang masih kurang. Untuk mengantisipasi kendalakendala diatas tersebut, maka diperlukan upaya-upaya untuk dapat menangani kendala tersebut baik dari faktor siswa, guru, dan sekolah.

\section{KESIMPULAN}

1. Strategi pembelajaran agama Hindu di Sekolah Luar Biasa C Negeri Bangli dilaksanakan dengan menggunakan strategi pembelajaran individual (individual learning) dan strategi exposition learning. Untuk strategi exposition learning dilakukan dengan cara memadukan metode ceramah dan metode direct introduction,

2. Kendala-kendala dalam pembelajaran agama Hindu di Sekolah Luar Biasa C Negeri Bangli yakni; 1) faktor siswa, siswa sering mengikuti keinginan sendiri dan susah untuk diatur, 2) faktor guru, guru sering sulit dalam memahami keinginan siswa akibat dari kondisi psikologis peserta didik yang berbedabeda; 3) faktor sekolah, kekurangan tenaga pendidik, sarana dan prasrana membuat terkadang proses belajar mengajar menjadi terhambat, terutama sarana media pembelajaran dan ruang kelas yang masih kurang. Untuk mengatisifasipasi kendala-kendala diatas tersebut, maka diperlukan upaya-upaya untuk dapat menangani kendala tersebut baik dari faktor siswa, guru, dan sekolah.

\section{DAFTAR PUSTAKA}

Ahmadi, A., \& Prasetya, J. T. (1997). Strategi Belajar Mengajar untuk Fakultas Tarbiyah Komponen MKDK. Bandung: Pustaka Setia.

Amin, M. (1995). Ortopedagogik anak tunagrahita. Jakarta: Depdikbud.
Amin, M. (1990). Pendidikan Anak Luar Biasa. Jakarta: Departemen Pendidikan dan Kebudayaan.

Suwandi, B. (2008). Memahami Penelitian Kualitatif. Jakarta: Rineka Cipta.

Cakir, M. (2008). Constructivist approaches to learning in science and their implications for science pedagogy: A literature review. Journal of Environmental \& Science Education. 3(4).

Dalyono, M. (1997). Pisikologi Pendidikan. Jakarta: Rineka Cipta.

Delphie, B. (2006). Pembelajaran Anak Berkebutuhan Khusus. Bandung: Refika Aditama.

Djiwandono, W. (2002). Psikologi Pendidikan. Jakarta: Grasindo.

Gulo, W. (2008). Strategi Belajar Mengajar. Jakarta; Grasindo.

Hasbulah (2006). Strategi Pembelajaran Inovatif Kontemporer. Jakarta: Bumi Aksara.

Martinis, Y. (2008). Strategi Pembelajaran Inovatif Kontemporer. Jakarta: Bumi Aksara.

Musfiqon. (2002). Pengembangan Media Belajar dan Sumber Belajar. Jakarta: Prestasi Pustaka Karya.

Mumpuniarti. (2007). Pendekatan Pembelajaran Bagi Hambatan Mental. Yogjakarta: Kanwa Publisher.

Palistini, N. L. A. (2018). Penerapan Metode Tutor Sebaya Untuk Meningkatkan Hasil Belajar Pendidikan Agama Hindu Pada Siswa Kelas III Sekolah Dasar Negeri 1 Sukadana. Jurnal Penjaminan Mutu, 4(1), 95-100.

Rusman. (2011). Model-Model Pembelajaran Mengembangkan Profesionalisme Guru. Jakarta: Rajawali Pers.

Sanjaya, W. (2008). Strategi Pembelajaran Berorientasi Proses Pendidikan. Jakarta: Kencana.

Slameto. (2003). Belajar Dan Faktor-Faktor Yang Mempengaruhinya. Jakarta: PT. Rineka Cipta.

Sutjihati, S. (2006). Psikologi Anak Luar Biasa. Bandung: Reflika Aditama.

Sudirman, dkk. (1991). Ilmu Pendidikan. Bandung: Remaja Rosdakarya Offset. 
Sukmadinata, N. S. (2004). Landasan Psikologi Proses Pendidikan. Bandung: PT. Remaja Rosdakarya.

Suprihatiningrum, J. (2013). Strategi Pembelajaran Teori Dan Aplikasi. Jogjakarta: Az-Ruzz Media.

Surya, M. (2004). Psikologi Pembelajaran Dan Pengajaran. Jogjakarta: Pustaka Bani Quarasy.

Trianto. (2010). Model pembelajaran Terpadu. Jakarta: Bumi Aksara.
Uno, H. (2008). Model Pembelajaran Kooperatif. Jakarta: Bumi Aksara

Wantah, M. (2007). Pengembangan Kemandirian Anak Tunagrahita Mampu Latih. Jakarta: Direktorat Jendral Pendidikan Tinggi.

Wardani, I.G.A.K. (2007). Pengantar Pendidikan Luar Biasa. Jakarta; Universitas Terbuka. 